\title{
PENGEMBANGAN MODUL MATAKULIAH STATISTIKA YANG TERINTEGRASI DENGAN MICROSOFT EXCEL DAN SPSS MENGGUNAKAN PENDEKATAN KECERDASAN LINGUISTIK
}

\author{
Filda Febrinita $^{1}$, Wahyu Dwi Puspitasari ${ }^{2}$, Sabitul Kirom ${ }^{3}$ \\ ${ }^{1}$ Teknik Informatika, Universitas Islam Balitar, Blitar \\ ${ }^{2,3}$ Sistem Komputer, Universitas Islam Balitar, Blitar \\ ${ }^{1}$ febrinitafilda80@gmail.com \\ 2pushpitasari23@gmail.com \\ ${ }^{3}$ sabitulkirom@gmail.com
}

\begin{abstract}
Abstrak: Modul merupakan salah satu bahan ajar yang dapat digunakan untuk membantu mencapai tujuan pembelajaran. Berdasarkan hasil observasi dan wawancara dengan dosen pengajar statistika dan mahasiswa prodi teknik informatika, dosen masih menggunakan bahan ajar berupa buku teks. Penyajian materi pada buku teks terkadang masih sulit dipahami mahasiswa. Namun, untuk mendapatkan buku teks yang lebih bagus pun, membutuhkan biaya yang relatif mahal. Oleh karena itu, perlu adanya bahan ajar yang memaparkan materi dengan jelas dan mudah dimengerti sehingga memudahkan mahasiswa dalam mempelajari statistika. Berdasarkan hal tersebut, dilakukanlah penelitian pengembangan yang bertujuan untuk menghasilkan modul matakuliah statistika yang terintegrasi dengan Excel dan SPSS menggunakan pendekatan kecerdasan linguistik, yang memenuhi kriteria valid, praktis dan efektif. Prosedur pengembangan produk mengikuti model pengembangan 4-D dari Thiagarajan tetapi pada penelitian ini tahapan yang digunakan adalah pendefinisian (define), perancangan (design), dan pengembangan (develop). Hasil penelitian menunjukkan nilai dari validasi ahli adalah 2,4 sehingga modul memenuhi kriteria valid. Hasil observasi keterlaksanaan modul adalah 2,54 sehingga modul memenuhi kriteria praktis. Sedangkan untuk nilai tes akhir, 78\% mahasiswa memperoleh nilai 75 ke atas. Selain itu, 61,6\% mahasiswa menyatakan setuju dan $34,9 \%$ mahasiswa menyatakan sangat setuju terhadap penggunaan modul dalam pembelajaran. Tercapainya ketuntasan belajar dan adanya respon positif tersebut menunjukkan bahwa modul memenuhi kriteria afektif. Berdasarkan hasil penelitian secara keseluruhan, dapat disimpulkan bahwa modul yang dikembangkan telah memenuhi kriteria valid, praktis dan efektif.
\end{abstract}

Katakunci:Modul; Statistika; Kecerdasan Linguistik.

\begin{abstract}
Modules are one of the teaching materials that can be used to help achieve learning goals. Based on the results of observations and interviews with statistical lecturers and informatics engineering study program students, lecturers still use textbooks to teach statistics. The presentation of material in textbooks is sometimes still difficult to understand by students. However, even to get a better textbook, it requires relatively expensive fees. Therefore, it's need teaching materials that explain the material clearly and easily understood so as to facilitate students in studying statistics. Based on this, development research was carried out which aims to produce a statistical course module that is integrated with Excel and SPSS using the linguistic intelligence approach, which meets valid, practical and effective criteria. The product development procedure follows the 4-D development model from Thiagarajan but in this research the stages used are defining, designing, and developing. The results showed the value of expert validation was 2.4 so the module met valid criteria. The results showed the value of expert validation was 2.4 so the module was included in the valid criteria. The result of observing the implementation of the module is 2.54 so the module is included in the practical criteria. While in the final test scores, $78 \%$ of students scored more than 75 . In addition, students gave positive responses, namely $61.6 \%$ agreed and $34.9 \%$ stated strongly
\end{abstract}


agree with the use of modules in learning. The achievement of mastery learning and the positive response shows that the module is included in the affective criteria. Based on the overall research results, it can be concluded that the modules developed have reached valid, practical and effective criteria

Keywords: Modules; Statistics; Linguistic Intelligence.

\section{Pendahuluan}

Program studi Teknik Informatika adalah prodi di Universitas Islam Balitar (Unisba) Blitar yang mewajibkan dosen untuk menggunakan bahan ajar yang relevan dalam proses pembelajaran di setiap matakuliah, salah satunya adalah matakuliah Statistika. Statistika adalah bagian dari ilmu matematika yang mempelajari tentang cara pengumpulan dan pengolahan data, analisis data, penarikan kesimpulan, serta penentuan keputusan yang berdasarkan pada data dan fakta yang sebenarnya (Riduwan, 2016). Statistika sangat penting untuk dipelajari khususnya bagi mahasiswa yang akan membuat karya ilmiah.

Berdasarkan hasil observasi dan wawancara penulis dengan dosen dan mahasiswa prodi TI, diperoleh informasi bahwa dosen masih menggunakan bahan ajar berupa buku teks pada matakuliah statistika. Namun, beberapa mahasiswa merasa kesulitan untuk memahami penjelasan materi yang tersaji pada buku tersebut. Selain itu, kesadaran mahasiswa untuk mau membeli buku cukup rendah sehingga tidak semua mahasiswa memiliki buku teks statistiska. Oleh karena itu, perlu adanya suatu bahan ajar yang diharapkan mampu mempermudah dosen dalam menyampaikan materi perkuliahan serta memudahkan mahasiswa untuk mempelajari dan memahami statistika.

Bahan ajar menjadi salah satu faktor dari keberhasilan proses pembelajaran (Devesh \& Nasseri, 2014). Bahan ajar yang tepat akan mempermudah tercapainya tujuan pembelajaran yang diharapkan. Bahan ajar juga memiliki pengaruh terhadap hasil belajar peserta didik (Swaditya \&
Nego, 2016). Selain itu, bahan ajar juga perlu disesuaikan dengan karakteristik peserta didik sebab tidak semua bahan ajar memaparkan materi dengan bahasa yang mudah dimengerti dan dipahami oleh peserta didik.

Modul merupakan salah satu bahan ajar yang dapat mendukung proses pembelajaran (Devesh \& Nasseri, 2014; Amalia \& Putra, 2017). Modul memuat unsur-unsur yaitu tujuan pembelajaran, materi belajar, serta evaluasi (Telaumbanua, Sinaga, Mukhtar, \& Surya, 2017). Modul adalah bahan ajar yang dapat digunakan oleh siswa untuk belajar mandiri, sehingga tanpa kehadiran guru siswa dapat belajar secara mandiri. Pengembangan modul memungkinkan siswa untuk menentukan kecepatan dan intensitas pembelajaran mereka sendiri (Izzati, Hindarto, \& Pamelasari, 2013). Selain itu, Modul membuat siswa belajar lebih sistematis (Wibowo, Supartono, \& Supardi, 2015). Oleh karena itu, penyusunan modul diharapkan dapat menghasilkan sarana belajar yang bersifat mandiri sehingga peserta didik mampu melakukan kegiatan belajar sesuai dengan kemampuan masing-masing.

Kemudahan bahan ajar dalam menyajikan materi dapat didukung dengan beberapa aplikasi komputer yang berkembang saat ini. Aplikasi yang sering digunakan dalam statistika diantaranya adalah Microsoft Excel dan Statistical Product and Service Solution (SPSS). Excel menyediakan fitur-fitur yang memungkinkan pengguna untuk mengatur, menganalisis, mengelola, dan berbagi informasi dengan mudah (Nielsen, 2016). Sama halnya dengan SPSS, aplikasi ini juga menyediakan berbagai fitur pengolahan data yang jauh 
lebih mudah untuk dioperasikan. User hanya perlu memasukkan data ke data editor kemudian memilih analisis yang diinginkan pada menu program. SPSS dapat digunakan untuk melakukan analisis data baik dengan statistika deskriptif maupun inferensial (Field, 2009). Selain itu, Excel dan SPSS merupakan aplikasi yang cukup mudah untuk diperoleh serta tidak membutuhkan memory dan ruang penyimpanan yang besar pada proses instalasinya. Berdasarkan penjabaran tersebut, pengintegrasian kedua aplikasi ini pada modul diharapkan dapat mempermudah mahasiswa untuk memahami materi statistiska yang dipelajari.

Pengintegrasian aplikasi pada modul membutuhkan penyajian dan pemaparan yang jelas. Aspek linguistik perlu dipertimbangkan untuk menghasilkan bahan ajar yang sesuai dengan karakter mahasiswa. Dengan mempertimbangkan aspek linguistik, diharapkan modul dapat melatih dan meningkatkan kecerdasan linguistik mahasiswa selama proses pembelajaran dengan modul. Kecerdasan linguistik adalah kemampuan dalam menggunakan bahasa, baik Bahasa ibu maupun bahasa asing untuk mengekspresikan berbagai hal yang ada di pikiran serta upaya untuk memahami orang lain (Yaumi, 2015). Kecerdasan linguistik merupakan kemampuan dalam menggunakan katakata secara efektif, baik digunakan untuk mempengaruhi maupun memanipulasi dan bermanfaat untuk peningkatan kemampuan membaca, menulis, mendengarkan, dan berbicara dalam kehidupan sehari-hari (Siswanto \& Lestari, 2012).

Beberapa penelitian telah dilakukan terkait dengan keefektifan modul dalam pembelajaran (Sadiq \& Zamir, 2014; Devesh \& Nasseri, 2014; Wardani, Nurhayati, \& Savitri, 2016; Telaumbanua, Sinaga, Mukhtar, \& Surya,
2017; Martiningsih, Lisdiana, \& Susilowati, 2018; Prawita, Prayitno, \& Sugiyarto, 2018). Dari beberapa penelitian tersebut diperoleh informasi bahwa penggunaan modul dalam pembelajaran sangat efektif untuk menilai proses pembelajaran, kinerja siswa serta hasil belajar siswa (Sadiq \& Zamir, 2014; Devesh \& Nasseri, 2014; Martiningsih, Lisdiana, \& Susilowati, 2018). Selain itu, penggunaan modul dalam pembelajaran juga mampu meningkatkan pemahaman konsep siswa, kemampuan berpikir analitis serta kemampuan pemecahan masalah siswa (Wardani, Nurhayati, \& Savitri, 2016; Telaumbanua, Sinaga, Mukhtar, \& Surya, 2017; Prawita, Prayitno, \& Sugiyarto, 2018). Dari segi linguistik, modul juga mampu meningkatkan motivasi siswa dalam membaca (Prawita, Prayitno, \& Sugiyarto, 2018).

Berdasarkan uraian di atas, sangat perlu untuk dibuat modul matakuliah statistika yang mudah dipahami serta sesuai dengan karakteristik mahasiswa program studi teknik informatika Unisba Blitar. Oleh karenanya, penulis melakukan penelitian untuk mengembangkan Modul Matakuliah Statistika yang Terintegrasi dengan Excel dan SPSS dengan Menggunakan Pendekatan Kecerdasan Linguistik.

\section{Metode Penelitian}

Penelitian ini merupakan jenis penelitian pengembangan yang sering disebut Research and Development. Prosedur pengembangan produk mengikuti model pengembangan 4-D (four-D Models) sesuai yang disarankan oleh Thiagarajan, dkk. Model 4-D terdiri atas 4 tahapan yaitu pendefinisian (define), perancangan (design), pengembangan (develop) dan penyebaran (disseminate) (Thiagarajan, Semmel, \& Semmel, 1974). Akan tetapi, untuk tahap 
penyebaran tidak dilaksanakan karena adanya keterbatasan waktu dan biaya. Penelitian dilakukan di Universitas Islam Balitar (Unisba) Blitar dengan subjek penelitian adalah mahasiswa semester IV tahun akademik $2018 / 2019$. Instrumen yang digunakan dalam penelitian ini adalah lembar validasi, lembar observasi keterlaksanaan modul, soal tes akhir, serta angket respon terhadap penggunaan modul. Pengujian yang dilakukan meliputi uji ahli/pakar (uji validasi), uji coba kelompok kecil serta uji coba kelompok besar.

Uji validasi oleh ahli/pakar akan digunakan untuk menentukan kevalidan dari modul. Uji coba kelompok kecil dan kelompok besar digunakan untuk menentukan kepraktisan dan keefektifan dari penggunaan modul dalam pembelajaran.

\section{Hasil dan Pembahasan}

Berdasarkan metode penelitian yang digunakan dalam penelitian ini, yaitu penelitian pengembangan, maka fokus dari hasil penelitian adalah pemaparan hasil pengukuran, penilaian, dan saran-saran selama proses penyusunan modul sampai uji coba lapangan. Pemaparan proses pengembangan modul serta temuan penelitian adalah sebagai berikut:

1. Pengembangan Instrumen Penelitian

Proses pengembangan modul pada penelitian ini menggunakan instrumen-instrumen penelitian, yaitu: 1) lembar validasi, 2) lembar observasi keterlaksanaan modul, 3) soal tes akhir, 4) angket respon terhadap penggunaan modul. Pengembangan instrumen ditujukan untuk mengukur aspek kevalidan, kepraktisan serta keefektifan.

Lembar validasi diisi oleh validator ahli. Validator ahli pada penelitian ini terdiri dari 2 orang ahli pendidikan matematika dan 1 orang ahli bahasa dan linguistik. Lembar validasi akan digunakan untuk mengukur beberapa aspek, yaitu: 1) kevalidan RPP, 2) kevalidan modul, 3) kevalidan lembar observasi keterlaksanaan modul dalam pembelajaran, 4) kevalidan soal tes akhir, 5) kevalidan angket respon penggunaan modul.

Selain lembar validasi, instrumen penelitian yang dikembangkan adalah lembar observasi, angket, dan soal tes akhir. Lembar observasi digunakan untuk mengamati keterlaksanaan modul dan aktivitas mahasiswa selama proses pembelajaran berlangsung. Angket digunakan untuk mengetahui respon mahasiswa terhadap penggunaan modul dalam pembelajaran. Melalui angket tersebut, mahasiswa dapat memberikan saran dan masukan yang akan digunakan sebagai bahan perbaikan modul. Selanjutnya, soal tes akhir digunakan untuk mengetahui tingkat penguasaan mahasiswa terhadap materi statistika yang disajikan di modul.

2. Pengembangan Modul

Sesuai dengan tujuan penelitian, modul yang akan dikembangkan memenuhi kriteria valid, praktis, dan efektif. Berikut akan dipaparkan hasil dari uji validasi, uji kepraktisan, dan uji keefektifan modul statistika yang terintegrasi dengan Excel dan SPSS dengan menggunakan pendekatan kecerdasan linguistik.

a. Uji Kevalidan Modul

Hasil validasi yang diperoleh dari validator ahli digunakan sebagai acuan untuk menentukan apakah modul memenuhi kriteria valid atau tidak. Selain itu, hasil validasi ini juga akan mendasari kesiapan modul untuk digunakan dalam uji coba lapangan. Proses 
validasi dilakukan dengan menyerahkan modul beserta instrumen penelitian lainnya pada validator ahli. Data hasil validasi secara keseluruhan dapat dilihat pada Tabel 1 berikut ini:

Tabel 1. Rekapitulasi Hasil Validasi Modul Statistika

\begin{tabular}{|c|c|c|c|c|c|}
\hline \multirow{2}{*}{\multicolumn{2}{|c|}{ Aspek yang Dinilai }} & \multicolumn{3}{|c|}{ Skor } & \multirow{2}{*}{$\boldsymbol{I}_{\boldsymbol{i}}$} \\
\hline & & \multirow[t]{2}{*}{$V_{1}$} & \multirow[t]{2}{*}{$V_{2}$} & \multirow[t]{2}{*}{$V_{3}$} & \\
\hline $\mathbf{A}$ & Organisasi Modul & & & & \\
\hline & $\begin{array}{l}\text { 1. Rumusan tujuan } \\
\text { pembelajaran }\end{array}$ & 2 & 2 & 3 & 2,3 \\
\hline & $\begin{array}{l}\text { 2. Rumusan pokok } \\
\text { bahasan }\end{array}$ & 2 & 2 & 2 & 2 \\
\hline & 3. Penjabaran materi & 2 & 2 & 2 & 2 \\
\hline & 4. Rangkuman materi & 2 & 1 & 2 & 1,7 \\
\hline & 5. Latihan soal & 2 & 2 & 2 & 2 \\
\hline & 6. Tes formatif & 3 & 3 & 2 & 2,7 \\
\hline & 7. Refleksi & 3 & 3 & 2 & 2,7 \\
\hline B & Prosedur & & & & \\
\hline & 1. Fisibilitas & 2 & 2 & 3 & 2,3 \\
\hline & 2. Urutan kerja & 2 & 2 & 3 & 2,3 \\
\hline & $\begin{array}{l}\text { 3. Adanya } \\
\text { aktivitas/kegiatan } \\
\text { yang } \\
\text { menunjukkan } \\
\text { keaktifan } \\
\text { mahasiswa } \\
\end{array}$ & 3 & 2 & 2 & 2,3 \\
\hline & $\begin{array}{l}\text { 4. Keterbacaan/ } \\
\text { bahasa }\end{array}$ & 3 & 3 & 3 & 3 \\
\hline $\mathbf{C}$ & $\begin{array}{l}\text { Pertanyaan/Masa- } \\
\text { lah }\end{array}$ & & & & \\
\hline & $\begin{array}{l}\text { 1. Kesesuaian antara } \\
\text { tujuan } \\
\text { pembelajaran } \\
\text { dengan pokok } \\
\text { bahasan }\end{array}$ & 2 & 2 & 2 & 2 \\
\hline & $\begin{array}{l}\text { 2. Masalah yang } \\
\text { disajikan } \\
\text { mendukung } \\
\text { pemahaman } \\
\text { konsep, prinsip } \\
\text { atau prosedur }\end{array}$ & 2 & 2 & 3 & 2,3 \\
\hline & $\begin{array}{l}\text { 3. Masalah yang } \\
\text { disajikan } \\
\text { meningkatkan } \\
\text { kecenderungan } \\
\text { mahasiswa untuk } \\
\text { menunjukkan } \\
\text { kemampuan } \\
\text { berpikir } \\
\end{array}$ & 3 & 3 & 2 & 2,7 \\
\hline
\end{tabular}

Lanjutan Tabel 1. Rekapitulasi Hasil Validasi Modul Statistika

\begin{tabular}{|c|c|c|c|c|c|}
\hline \multirow{2}{*}{\multicolumn{2}{|c|}{ Aspek yang Dinilai }} & \multicolumn{3}{|c|}{ Skor } & \multirow{3}{*}{$\boldsymbol{I}_{\boldsymbol{i}}$} \\
\hline & & \multirow[t]{2}{*}{$V_{1}$} & \multirow[t]{2}{*}{$V_{2}$} & \multirow[t]{2}{*}{$V_{3}$} & \\
\hline $\mathbf{C}$ & $\begin{array}{l}\text { Pertanyaan/Masa- } \\
\text { lah }\end{array}$ & & & & \\
\hline & $\begin{array}{l}\text { 4. Masalah yang } \\
\text { disajikan melatih } \\
\text { kemampuan } \\
\text { mahasiswa dalam } \\
\text { bidang linguistik } \\
\text { yang meliputi } \\
\text { membaca, } \\
\text { memahami } \\
\text { masalah, menulis, } \\
\text { dan } \\
\text { mengungkapkan } \\
\text { pendapat/ide } \\
\text { dengan bahasanya } \\
\text { sendiri. }\end{array}$ & 2 & 3 & 3 & 2,7 \\
\hline & $\begin{array}{l}\text { 5. Masalah yang } \\
\text { disajikan } \\
\text { menggunakan } \\
\text { bahasa yang } \\
\text { mudah dipahami } \\
\text { serta penulisan } \\
\text { yang sesuai } \\
\text { dengan EYD }\end{array}$ & 2 & 2 & 3 & 2,3 \\
\hline
\end{tabular}

Berdasarkan hasil dari Tabel 1, diperoleh skor rata-rata untuk aspek organisasi modul adalah 2,2. Skor rata-rata untuk aspek prosedur adalah 2,5 sedangkan skor rata-rata untuk aspek pertanyaan/masalah adalah 2,4. Dari skor rata-rata ketiga aspek tersebut $\left(V_{a}\right)$, diperoleh rata-rata seluruh aspek adalah 2,37 atau 2,4. Ini artinya, nilai $V_{a}$ berada pada interval $2 \leq V_{a} \leq 3$ (valid). Sehingga, dapat disimpulkan bahwa draft modul statistika berada pada kategori valid.

b. Uji Kepraktisan Modul

Uji kepraktisan modul dilakukan dengan melihat keterlaksanaan modul dalam pembelajaran. Sebelum modul digunakan dalam pembelajaran, terlebih dahulu dilakukan uji coba kelompok kecil, dengan subyek 6 orang mahasiswa. Pengujian ini 
bertujuan untuk mengamati keterbacaan modul. Hasil uji coba kelompok kecil yang diperoleh adalah sebagai berikut:

1) Mahasiswa dapat menyelesaikan modul sesuai dengan waktu yang dialokasikan.

2) Mahasiswa menemukan beberapa kekurangan yang meliputi kesalahan tanda baca, kesalahan pengetikan kata atau kalimat, serta penjelasan beberapa materi yang dirasa sulit untuk dipahami.

Temuan mahasiswa terkait dengan keterbacaan modul, dapat dilihat pada Tabel 2. berikut.

Tabel 2. Daftar Temuan Mahasiswa pada Uji Coba Kelompok Kecil

\begin{tabular}{|c|c|}
\hline $\begin{array}{l}\text { Modul/ } \\
\text { Hal. }\end{array}$ & Kata yang salah ketik \\
\hline $1 / 14$ & $\begin{array}{l}\text { pilihan jawaban untuk no.4 yang } \\
\text { (b) tertulis htrogen }\end{array}$ \\
\hline $1 / 15$ & $\begin{array}{l}\text { Pilihan jawaban untuk no.5 yang } \\
\text { (a) tertulis ssus }\end{array}$ \\
\hline $2 / 22$ & $\begin{array}{l}\text { Penulisan rumus ( } 2.1) \text { belum } \\
\text { menggunakan equation seperti } \\
\text { rumus-rumus yang lain }\end{array}$ \\
\hline $2 / 41$ & $\begin{array}{l}\text { Kata berbahasa inggris di langkah } \\
\text { pembuatan grafik histogram dengan } \\
\text { excell belum dicetak miring. }\end{array}$ \\
\hline $2 / 178$ & $\begin{array}{l}\text { Keterangan gambar dengan perintah } \\
\text { tidak sinkron. } \\
\text { Pada perintah tertulis, "Perhatikan } \\
\text { Gambar 7.36" tetapi keterangan } \\
\text { pada gambar adalah, "Gambar } \\
7.35 \text { " }\end{array}$ \\
\hline $6 / 136$ & $\begin{array}{l}\text { Penomoran gambar salah, } \\
\text { seharusnya Gambar } 6.5 \text { tertulis } \\
\text { Gambar } 6.4\end{array}$ \\
\hline $6 / 138$ & $\begin{array}{l}\text { Penomoran gambar salah, } \\
\text { seharusnya Gambar } 6.6 \text { tertulis } \\
\text { Gambar } 6.5\end{array}$ \\
\hline $6 / 138$ & $\begin{array}{l}\text { Kesalahan pengetikan kata } \\
\text { seharusnya provokator tertulis } \\
\text { provoktor }\end{array}$ \\
\hline $8 / 183$ & $\begin{array}{l}\text { Di poin c tertulis Modul III } \\
\text { seharusnya Modul VII karena pada } \\
\text { modul III tidak membahas taraf } \\
\text { signifikansi. }\end{array}$ \\
\hline
\end{tabular}

Lanjutan Tabel 2. Daftar Temuan Mahasiswa pada Uji Coba Kelompok Kecil

\begin{tabular}{|c|c|}
\hline $\begin{array}{c}\text { Modul/ } \\
\text { Hal }\end{array}$ & Hal yang Perlu Diperbaiki \\
\hline $2 / 25$ & $\begin{array}{l}\text { Penjelasan tentang distribusi frekuensi } \\
\text { relatif membingungkan dan muncul } \\
\text { rumus yang sama berulang kali dan } \\
\text { terdapat penulisan variabel yang salah. } \\
f_{1}=\frac{f_{1}}{5} \times 100 \% \sum_{i=1} f \cdot i \\
f_{2}=\frac{f_{2}}{5} \times 100 \% \sum_{i=1} f \cdot i \\
f_{3}=\frac{f_{3}}{5} \times 100 \% \sum_{i=1} f \cdot i \\
f_{4}=\frac{f_{4}}{5} \times 100 \% \sum_{i=1} f \cdot i \\
f_{5}=\frac{f_{5}}{5} \times 100 \% \sum_{i=1} f \cdot i\end{array}$ \\
\hline $5 / 118$ & $\begin{array}{l}H_{0}: \quad \mu_{1}=400 \text { jam } \\
H_{a}: \quad \mu_{2}=400 \text { jam } \\
\text { Tidak ada } \mu_{1} \text { dan } \mu_{2}, \text { tapi tiba tiba } \\
\text { muncul } \mu_{1} \text { dan } \mu_{2}\end{array}$ \\
\hline $5 / 119$ & $\begin{array}{l}\text { Pada Contoh } 5.10 \text { hipotesis alternatif } \\
\text { tertulis dua kali dengan isi yang } \\
\text { berbeda } \\
\text { Hipotesis alternatif: } \\
\text { Daya tahan lampu merk } A \text { lebih kecil } \\
400 \text { jam } \\
\text { Hipotesis alternatif } \\
H_{0}: \quad \mu \geq 400 \text { jam } \\
H_{a}: \mu<400 \text { jam }\end{array}$ \\
\hline $5 / 124$ & $\begin{array}{l}\text { ("lebih besar atau sama dengan" } \\
=\text { "paling sedikit") } \\
\text { ("lebih kecil atau sama dengan" } \\
=\text { "paling besar") } \\
\text { Kalimatnya membingungkan }\end{array}$ \\
\hline & $\begin{array}{l}\text { Berdasarkan hasil temuan } \\
\text { tersebut maka dilakukan revisi } \\
\text { terhadap modul. Hasil revisi } \\
\text { seperti yang dipaparkan pada } \\
\text { Tabel 3. Berikut: }\end{array}$ \\
\hline
\end{tabular}

Tabel 3. Revisi Modul setelah Uji Coba Kelompok Kecil

\begin{tabular}{cll}
\hline $\begin{array}{c}\text { Modul } \\
\text { / Hal }\end{array}$ & \multicolumn{1}{c}{ Sebelum Revisi } & Setelah Revisi \\
\hline $1 / 14$ & $\begin{array}{l}\text { pilihan jawaban no.4 } \\
\text { yang (b) tertulis } \\
\text { htrogen }\end{array}$ & $\begin{array}{l}\text { jawaban no.4 } \\
\text { yang (b) tertulis } \\
\text { hetrogen }\end{array}$ \\
\hline $1 / 15$ & $\begin{array}{l}\text { Pilihan jawaban no.5 } \\
\text { (a) tertulis ssus }\end{array}$ & $\begin{array}{l}\text { Pilihan jawaban } \\
\text { no.5 (a) tertulis } \\
\text { sensus }\end{array}$ \\
\hline $2 / 22$ & $\begin{array}{l}\text { Rumus 2.1 belum } \\
\text { menggunakan } \\
\text { equation }\end{array}$ & $\begin{array}{l}\text { Rumus } 2.1 \\
\text { ditulis ulang } \\
\text { dengan } \text { equation }\end{array}$ \\
\hline $2 / 41$ & $\begin{array}{l}\text { Kata berbahasa } \\
\text { inggris belum } \\
\text { tercetak miring }\end{array}$ & $\begin{array}{l}\text { Kata berbahasa } \\
\text { inggris telah } \\
\text { tercetak miring }\end{array}$ \\
\hline
\end{tabular}


Lanjutan Tabel 3. Revisi Modul setelah Uji Coba Kelompok Kecil

\begin{tabular}{|c|c|c|}
\hline $\begin{array}{l}\text { Modul } \\
\text { / Hal }\end{array}$ & Sebelum Revisi & Setelah Revisi \\
\hline $2 / 25$ & $\begin{array}{l}f_{1}=\frac{f_{1}}{5} \times 100 \\
\% \sum_{i=1} f \cdot i \\
f_{2}=\frac{f_{2}}{5} \times 100 \\
\% \sum_{i=1} f \cdot i \\
f_{3}=\frac{f_{3}}{5} \times 100 \\
\% \sum_{i=1} f \cdot i \\
f_{4}=\frac{f_{4}}{5} \times 100 \\
\% \sum_{i=1} f \cdot i \\
f_{5}=\frac{f_{5}}{5} \times 100 \\
\% \sum_{i=1} f \cdot i\end{array}$ & $\begin{array}{l}f_{1}^{\prime}=\frac{f_{1}}{\mathrm{n}} \times 100 \% \\
f_{2}^{\prime}=\frac{f_{2}}{\mathrm{n}} \times 100 \% \\
f_{3}^{\prime}=\frac{f_{3}}{\mathrm{n}} \times 100 \% \\
f_{4}^{\prime}=\frac{f_{4}}{\mathrm{n}} \times 100 \% \\
f_{5}^{\prime}=\frac{f_{5}}{\mathrm{n}} \times 100 \\
\% \\
\text { dengan, } \\
n=\text { jumlah total } \\
\text { frekuensi } \\
f_{1}=\text { frekuensi } \\
\text { kelas pertama } \\
f_{2}=\text { frekuensi } \\
\text { kelas pertama } \\
f_{3}=\text { frekuensi } \\
\text { kelas pertama } \\
f_{4}=\text { frekuensi } \\
\text { kelas pertama } \\
f_{5}=\text { frekuensi } \\
\text { kelas pertama }\end{array}$ \\
\hline $5 / 118$ & $\begin{array}{l}H_{0}: \mu_{1}=400 \mathrm{jam} \\
H_{a}: \mu_{2}=400 \mathrm{jam}\end{array}$ & $\begin{array}{l}H_{0}: \mu=400 \\
\text { jam } \\
H_{a}: \mu \neq 400 \\
\text { jam }\end{array}$ \\
\hline $5 / 119$ & $\begin{array}{l}\text { Hipotesis alternatif } \\
H_{0}: \mu \geq 400 \text { jam } \\
H_{a}: \mu<400 \text { jam }\end{array}$ & $\begin{array}{l}H_{0}: \mu \geq 400 \\
\text { jam } \\
H_{a}: \mu<400 \\
\text { jam }\end{array}$ \\
\hline $5 / 124$ & $\begin{array}{l}\text { ("lebih besar atau } \\
\text { sama dengan" } \\
=\text { "'paling sedikit") } \\
\text { ("lebih kecil atau } \\
\text { sama dengan" } \\
=\text { "paling besar") }\end{array}$ & $\begin{array}{l}\text { (kalimat "lebih } \\
\text { besar atau sama } \\
\text { dengan" sama } \\
\text { artinya dengan } \\
\text { "paling sedikit") } \\
\text { (kalimat "lebih } \\
\text { kecil atau sama } \\
\text { dengan" sama } \\
\text { artinya dengan } \\
\text { "paling besar") }\end{array}$ \\
\hline $6 / 136$ & $\begin{array}{l}\text { Penomoran Gambar } \\
6.5 \text { tertulis Gambar } \\
6.4\end{array}$ & $\begin{array}{l}\text { Penomoran } \\
\text { disesuaikan, } \\
\text { yaitu Gambar } \\
6.5 \\
\end{array}$ \\
\hline $6 / 138$ & $\begin{array}{l}\text { Penomoran Gambar } \\
6.6 \text { tertulis Gambar } \\
6.5 \text {. }\end{array}$ & $\begin{array}{l}\text { Penomoran } \\
\text { disesuaikan, } \\
\text { yaitu Gambar } \\
6.6 \\
\end{array}$ \\
\hline $6 / 138$ & $\begin{array}{l}\text { Tertulis kata } \\
\text { "provoktor" }\end{array}$ & $\begin{array}{l}\text { Tertulis } \\
\text { "provokator" }\end{array}$ \\
\hline
\end{tabular}

Setelah modul direvisi, dilakukan uji lapangan pada kelompok besar dengan menerapkan modul pada pembelajaran. Dari proses pembelajaran tersebut, diperoleh data tentang keterlaksanaan modul melalui lembar observasi keterlaksanaan modul. Hasil observasi keterlaksanaan modul yang telah dikembangkan dapat dilihat pada Tabel 4 berikut.

Tabel 4. Rekapitulasi Hasil Observasi Keterlaksanaan Modul Statistika dalam Pembelajaran

\begin{tabular}{|c|c|c|c|c|}
\hline \multirow{2}{*}{$\begin{array}{c}\text { Pertemuan } \\
\text { ke - }\end{array}$} & \multicolumn{2}{|c|}{ Skor } & \multirow{2}{*}{$\begin{array}{l}\text { Rata- } \\
\text { Rata }\end{array}$} & \multirow{2}{*}{$V_{a}$} \\
\hline & $O b s_{1}$ & $\mathrm{Obs}_{2}$ & & \\
\hline 1 & 2,45 & 2,64 & 2,55 & \multirow{8}{*}{2,54} \\
\hline 2 & 2,36 & 2,55 & 2,46 & \\
\hline 3 & 2,73 & 2,64 & 2,69 & \\
\hline 4 & 2,55 & 2,55 & 2,55 & \\
\hline 5 & 2,45 & 2,36 & 2,41 & \\
\hline 6 & 2,64 & 2,45 & 2,55 & \\
\hline 7 & 2,36 & 2,55 & 2,46 & \\
\hline 8 & 2,64 & 2,73 & 2,69 & \\
\hline
\end{tabular}

Berdasarkan hasil observasi pada keterlaksanaan modul dalam uji kelas besar, diperoleh skor rata-rata $\left(V_{a}\right)$ dari dua observer adalah 2,54. Ini artinya $V_{a}$ berada pada interval $2 \leq V_{a} \leq 3$ sehingga dapat disimpulkan bahwa tingkat kepraktisan modul yang dikembangkan berada pada kriteria tinggi.

c. Uji Keefektifan Modul

Dalam penelitian ini, modul dikatakan efektif apabila memenuhi dua kriteria yaitu: a) mahasiswa mengalami ketuntasan belajar dengan menggunakan modul, b) mahasiswa memberikan respon positif pada penggunaan modul dalam pembelajaran. Ketuntasan belajar dengan mengunakan modul dicapai apabila lebih dari $75 \%$ jumlah mahasiswa memperoleh nilai akhir lebih dari 75. Berikut dipaparkan data ketuntasan belajar 


$$
\begin{aligned}
& \text { mahasiswa pada } \begin{array}{r}
\text { proses } \\
\text { dengan }
\end{array} \\
& \text { pembelajaran } \\
& \text { menggunakan modul statistika. }
\end{aligned}
$$

\begin{tabular}{|c|c|c|c|c|}
\hline No. & Nama & $\begin{array}{c}\text { Rata- } \\
\text { rata Tes } \\
\text { Formatif } \\
\end{array}$ & $\begin{array}{c}\text { Nilai } \\
\text { Tes } \\
\text { Akhir }\end{array}$ & $\begin{array}{c}\text { Nilai } \\
\text { Akhir }\end{array}$ \\
\hline 1. & ZAR & 83 & 69 & 74 \\
\hline 2. & $\mathrm{ZF}$ & 84 & 78 & 80 \\
\hline 3. & RSJ & 84 & 78 & 80 \\
\hline 4. & LMS & 88 & 75 & 80 \\
\hline 5. & RAA & 91 & 88 & 89 \\
\hline 6. & DS & 81 & 70 & 75 \\
\hline 7. & DDI & 81 & 74 & 77 \\
\hline 8. & MAW & 86 & 80 & 83 \\
\hline 9. & VYT & 88 & 73 & 79 \\
\hline 10. & MFNH & 83 & 85 & 84 \\
\hline 11. & YUQ & 81 & 68 & 73 \\
\hline 12. & WN & 85 & 70 & 76 \\
\hline 13. & RY & 80 & 80 & 80 \\
\hline 14. & $\mathrm{YN}$ & 90 & 81 & 85 \\
\hline 15. & AMI & 91 & 76 & 82 \\
\hline 16. & WEF & 88 & 65 & 74 \\
\hline 17. & BKS & 85 & 69 & 75 \\
\hline 18. & MFA & 86 & 69 & 76 \\
\hline 19. & RWK & 83 & 66 & 73 \\
\hline 20. & NPP & 91 & 80 & 85 \\
\hline 21. & RA & 89 & 73 & 79 \\
\hline 22. & $\mathrm{MSN}$ & 84 & 88 & 86 \\
\hline 23. & IAP & 91 & 70 & 79 \\
\hline 24. & MRA & 91 & 67 & 77 \\
\hline 25. & DNP & 94 & 71 & 80 \\
\hline 26. & ETW & 85 & 81 & 83 \\
\hline 27. & $\mathrm{AB}$ & 89 & 67 & 76 \\
\hline 28. & $\mathrm{DF}$ & 83 & 80 & 81 \\
\hline 29. & DS & 95 & 77 & 84 \\
\hline 30. & IM & 84 & 78 & 80 \\
\hline 31. & DFF & 90 & 77 & 82 \\
\hline 32. & MS & 90 & 85 & 87 \\
\hline 33. & $\mathrm{KJ}$ & 84 & 68 & 74 \\
\hline 34. & RRA & 86 & 73 & 78 \\
\hline 35. & AAK & 85 & 72 & 77 \\
\hline 36. & DSP & 89 & 68 & 76 \\
\hline 37. & $\mathrm{DU}$ & 81 & 70 & 75 \\
\hline 38. & $\mathrm{AG}$ & 84 & 66 & 73 \\
\hline 39. & RAM & 81 & 69 & 74 \\
\hline 40. & SSP & 88 & 76 & 81 \\
\hline
\end{tabular}

Tabel 5. Rekapitulasi Data Ketuntasan Belajar Mahasiswa dengan Menggunakan Modul

Berdasarkan data pada Tabel 5 , dapat diketahui bahwa 9 dari 40 mahasiswa memperoleh nilai akhir di bawah 75. Ini artinya ketuntasan belajar mahasiswa dengan menggunakan modul secara klasikal mencapai $78 \%$. Berdasarkan persentase ini, dapat dikatakan bahwa ketuntasan belajar mahasiswa dengan menggunakan modul yang dikembangkan telah terpenuhi.

Selain tercapainya ketuntasan belajar, mahasiswa juga memberikan respon positif terhadap penggunaan modul dalam pembelajaran. Dari 40 angket respon yang diberikan pada mahasiswa, $61,6 \%$ mahasiswa menyatakan setuju dan $34,9 \%$ mahasiswa menyatakan sangat setuju bahwa penggunaan modul dalam pembelajaran dapat membantu mereka untuk memahami dan mempelajari materi statistika dasar. Ini artinya, mahasiswa memberikan respon positif terhadap penggunaan modul dalam pembelajaran matakuliah statistika.

\section{Kesimpulan}

Berdasarkan hasil dari proses penelitian pengembangan yang telah dilakukan, maka dapat diperoleh kesimpulan sebagai berikut.

1. Modul untuk matakuliah statistika yang terintergrasi dengan Excel dan SPSS dengan menggunakan pendekatan kecerdasan linguistik telah tersusun dan tervalidasi oleh Ahli, dengan skor 2,4. Ini artinya modul yang dikembangkan telah memenuhi kriteria valid.

2. Modul untuk matakuliah statistika yang terintergrasi dengan Excel dan SPSS dengan menggunakan pendekatan kecerdasan linguistik telah digunakan dalam pembelajaran dan memperoleh skor hasil observasi keterlaksanaan modul yaitu 2,54. Ini artinya bahwa modul yang telah 
dikembangkan memenuhi kriteria praktis.

3. Penggunaan modul statistika yang terintergrasi dengan Excel dan SPSS dengan menggunakan pendekatan kecerdasan linguistik dalam pembelajaran telah memenuhi kriteria efektif, yang ditunjukkan dengan: a) tercapainya ketuntasan belajar secara klasikal, yaitu $78 \%$ mahasiswa memperoleh nilai akhir lebih dari 75, b) adanya respon positif dari mahasiswa yaitu $61,6 \%$ mahasiswa menyatakan setuju dan $34,9 \%$ mahasiswa menyatakan sangat setuju bahwa modul membantu mereka untuk memahami dan mempelajari materi statistika dasar.

Selain itu, terdapat beberapa saran yang dapat digunakan untuk melakukan penelitian pengembangan berikutnya, yaitu:

1. Modul yang dikembangkan hanya terbatas pada materi statistika dasar sehingga perlu adanya perluasan materi untuk modul berikutnya

2. Melakukan pengembangan lebih lanjut untuk menghasilkan modul yang terintegrasi dengan aplikasi pengolahan statistik yang lain, misalnya Minitab, Statistical Analysis System (SAS), atau Staltat

\section{Ucapan Terimakasih}

Dengan terselesaikannya Jurnal Ilmiah ini, penulis mengucapkan terima kasih kepada Direktur Riset dan Pengabdian Masyarakat (DRPM) Kementerian Riset, Teknologi, dan Pendidikan Tinggi yang telah mendanai penelitian ini melalui penelitian hibah bersaing Dikti 2019. Semoga hasil dari penelitian ini bisa memberikan manfaat yang positif bagi peningkatan kualitas pendidikan khususnya di lingkup FTI Unisba Blitar.

\section{Daftar Rujukan}

Amalia, R., \& Putra, E. D. (2017). Pengembangan Modul Mata Kuliah Algoritma dan Pemrograman (Pemrogaman C++). GAMMATH : Jurnal Ilmiah Program Studi Pendidikan Matematika, 2(2), 1 - 8.

Devesh, S., \& Nasseri, D. A. (2014). Effectiveness of Mathematics Module in Fundation Programme in Majan Collage. International Journal of Engineering Research and Technology, 2(1), 1-7.

Field, A. (2009). Discovering Statistics Using SPSS - Third Edition. Singapore: Sage.

Izzati, N., Hindarto, N., \& Pamelasari, S. D. (2013). Pengembangan Modul Tematik dan Invatif Berkarakter pada Tema Pencemaran Lingkungan untuk Siswa Kelas VII SMP. Jurnal Pendidikan IPA Indonesia, 2(2), 183-188.

Martiningsih, I., Lisdiana, \& Susilowati, S. E. (2018). Development of Module on Scientific Contextual Additives Material to Increase Learning Outcome and Science Process Skill in Junior High School. Journal of Innovative Science Education, 7(2), 372 381.

Nielsen, J. J. (2016). Microsoft Official Academic Course Microsoft Excel 2016. Hoboken: Wiley.

Prawita, W., Prayitno, B. A., \& Sugiyarto. (2018). Effectiveness of A Generative Learning - Based Biology Module to Improve the Analytical Thinking Skill of the Students with High and Low Reading Motivation. International Journal of Instruction, 12(1), 1459 - 1476.

Riduwan. (2016). Dasar-Dasar Statistika. Bandung: Alfabeta. 
Sadiq, S., \& Zamir, S. (2014). Effectiveness of Modular Approach in Teaching at University. Journal of Education and Practice, 5(17), 103 - 109.

Siswanto, I., \& Lestari, S. (2012). Panduan bagi Guru dan Orang Tua : Pembelajaran Atraktif dan 100 Permainan Kreatif untuk PAUD. Yogyakarta: ANDI.

Swaditya, R., \& Nego, L. (2016). Pengembangan Bahan Ajar Program Linear Berbasis Kontekstual dan ICT. Jurnal Aksioma, 5(2), 137-144.

Telaumbanua, Y. N., Sinaga, B., Mukhtar, \& Surya, E. (2017). Development of Mathematics Module Based on Metakognitive Strategy in Improving Students' Mathematical Problem Solving Ability High School. Journal of Education and Practice, 8(19), 73-80.

Thiagarajan, S., Semmel, D., \& Semmel, M. (1974). Instructional
Development for Training Teachers of Exceptional Children. Minneapolis, Minnesota: Leadership Training Institute/Special Education, University of Minnesota.

Wardani, S., Nurhayati, S., \& Savitri, A. (2016). The Effectiveness of the Guided Inquiry Learning Module Towards Students' Character and Concept Understanding. International Journal of Science and Research, 5(6), 1589 - 1594.

Wibowo, T., Supartono, \& Supardi, K. I. (2015). Pengembangan Modul Termokia dengan Pendekatan Inkuiri Terpadu Pendidikan Karakter untuk Meningkatkan Logika Siswa. Journal of Innovative Science Education, 4(1), 1-6.

Yaumi, M. (2015). Desain Strategi Pembelajaran untuk Mengembangkan Kecerdasan Verbal-Linguistik Peserta Didik. Auladana, 2(1), 185-200. 